\title{
Morphobiometry and Growth Performances of Improved Genetic Types of Chickens (Gallus Gallus) Raised in Cameroon
}

\author{
Francois Djitie Kouatcho ${ }^{1 *}$, Razvan Mihail Radu-Rusu², Dan-Claudiu Roşca ${ }^{2}$, Sotche \\ Merveil Steve ${ }^{1}$, Eliza Simiz ${ }^{3}$ \\ ${ }^{1}$ University of Ngaoundéré, Department of Biological Sciences, Faculty of Sciences, Po Box 454 \\ Ngaoundéré, Cameroon \\ ${ }^{2}$ University of Agricultural Sciences and Veterinary Medicine Iaşi, Faculty of Animal Science, 3 Mihail \\ Sadoveanu Alley, 700490 laşi, Romania \\ ${ }^{3}$ Banat University of Agricultural Science and Veterinary Medicine, Bioenginering Faculty of Animal \\ Resources, Timisoara 119, Calea Aradului, Timisoara 300645, Romania
}

\begin{abstract}
From July to November 2019, a study has been carried out in the locality of Ngaoundéré in order to contribute to a better knowledge of exotic hens. For this purpose, 190 improved strain chicks of one day-old with an average weight of $35.49 \pm 3.78 \mathrm{~g}$ were distributed according to the type of feather. They were fed an iso-energetic and iso-proteic feed. Data on phenotype characteristics, growth performance, biometric data and carcass were determined. The main results show that three types of feathering were recorded with $16.4 \%$ of hens with bare necks and with feathered pits, $78.1 \%$ of hens with feathered pits and $5.5 \%$ of hens with normal feathers. The majority of hens were recorded with a single comb $(75.3 \%)$, round mumps $(71.2 \%)$, white pits $(76.4 \%)$, black beaks $(47.9 \%)$ and brown eyes $(75.3 \%)$. In terms of zootechnical performance, the highest live weight $(1758.00 \pm 322.20 \mathrm{~g})$ was recorded with naked-necked hens and feathered pits. The highest weekly average weight gain was recorded with yellow eyed hens $(111.77 \pm 16.63 \mathrm{~g})$ followed by bare-necked and feathered pits $(107.83 \pm 20.06 \mathrm{~g})$. Hens expressing the $\mathrm{Na}$ and Pti genes showed the best growth performance although carcass yield was not significantly affected by feather type. It was concluded that there is a very high phenotypic diversity in the so-called improved hens. However, despite their great potential, responsible management of this genetic resource should be encouraged in order to avoid genetic erosion of local poultry resources.
\end{abstract}

Keywords: chickens, phenotype, morphology, biometry, growth characteristics.

\section{Introduction}

Poultry farming is a component of food security and a significant source of income for many families [1]. In Cameroon, the sector generates an estimated annual profit of about 15 billion CFA francs and covers $14 \%$ of the population's animal protein needs [2]. Despite their low productivity, local chicken populations represent $70 \%$ of the

\footnotetext{
* Corresponding author: Francois D. Kouatcho, Email: franckdjitie@gmail.com

(cc) EY-NC-ND ( 2021 F.D. Kouatcho et al., published by De Gruyter Open. This work was licensed under the Creative Commons Attribution-NonCommercialNoDerivs 3.0 License
}

poultry flock and selected strains of chicken constitute $24 \%$ of this flock [3].

According to Bordas et al [4], the genetic potential of local breeds and their contribution to the establishment of future sustainable management strategies requires prior knowledge of the diversity of available genotypes. Therefore, a lot of work has been done on the characterisation of the local chicken $[5,6]$, egg quality and growth performance of local chicks [5], evaluation and prediction of the effect of genetic type on the evolution of live weight of local chickens [7], socioeconomic survey and family poultry farming techniques [8]. Nevertheless, to the best of our knowledge, no study has yet been carried out on 
the characterisation of exotic hens integrated in a relatively anarchic way into the local poultry population in Cameroon with the aim of contributing to the rapid increase of production. The lack of knowledge of the different genetic types of local and exotic chickens and the constraints related to their production make it extremely difficult to exploit these genes effectively and to set up a development programme that can optimally benefit the local population, according to Keambou et al [5]. The present study aims to contribute to a better understanding of improved chickens in Cameroon. Specifically, the morpho-biometric and growth characteristics of exotic chicken populations in the Sudano-Guinean zone of Cameroon were described.

\section{Material and Methods}

\section{Ethical approval}

Experimental protocols used in this study were approved by the ethic comity of the Faculty of Sciences, University of Ngaoundere, Cameroon and strictly conformed with the internationally accepted standard ethical guidelines for laboratory animal use and care as described in the European Community guidelines; EEC Directive 86/609/EEC, of the 24th November 1986.

\section{Study area}

The present study was carried out in Ngaoundéré, the capital of the Adamaoua region in Cameroon and is located between the 6th and 8th degrees of North latitude and the 11th and 15th degrees of East longitude. It covers about $62,000 \mathrm{~km} 2$ and belongs to the agro-ecological zone known as the high Guinean savannahs. The climate is SudanoGuinean, mild and cool, characterised by two seasons: a rainy season (April to October) and a dry season (November to March). The average annual temperature varies from 23 to $25^{\circ} \mathrm{C}$ and annual rainfall varies between 900 and $1500 \mathrm{~mm}$ for an average annual humidity varying between 64.1 and $67.6 \%$.

\section{Animal materials and experimental design}

The animal material consisted of 190 improved strain chicks of one day-old with an average weight of $35.49 \pm 3.78 \mathrm{~g}$. For the first 6 weeks, the chicks were divided by feathering type (Normal, feathered tarsus and feathered naked necktarsus) and housed at a density of 18 chicks $/ \mathrm{m}^{2}$ in pens made of plywood. After 6 weeks, they were housed at a density of 6 chicks $/ \mathrm{m}^{2}$ in a rearing room divided with wire mesh. They received the same diets (PB 20\% ME and $3000 \mathrm{kcal} / \mathrm{kg}$ up to 6 weeks and PB 18\% ME and $2800 \mathrm{kcal} / \mathrm{kg}$ after 6 weeks) according to the rearing phase.

\section{Data collection}

Data were collected mainly according to feathering type but also according to other morphological and visual criteria such as comb shape and color and also tarsal shape.

\section{Growth performance}

During the duration of the trial (16 weeks), growth characteristics (feed intake, live weight, weight gain and feed conversion ratio) were recorded every 7 days. For each experimental unit, the weekly feed intake was calculated as the difference between the amount of feed distributed and the remaining feed, all weighed using an electronic scale with a capacity of $5000 \mathrm{~g}$ and accuracy of $1 \mathrm{~g}$.

At the beginning of the trial and every 7 days thereafter, birds were weighed fasting in the morning using a $500 \mathrm{~g}$ capacity, $0.1 \mathrm{~g}$ precision electronic scale. After 6 weeks, weighing was done with the scale used for the feed. Weekly weight gain was obtained as the difference between two consecutive live weights.

Data on feed intake $(\mathrm{FI})$ for the week and average weekly weight gain (AWG) for the same period were used to calculate the feed conversion ratio (FCR) as follows:

$$
\mathrm{FCR}=\frac{\text { Weekly Feed Intake }(g)}{\text { Weekly Weight Gain }(g)}
$$

\section{Morpho-biometric characteristics}

Morpho-biometric characteristics were collected every 14 days by direct visual observations according to the standards recommended by FAO [9]. These data mainly included feathering type, comb type, auricle color and shape, beak color and shape, leg and eye colors; body length, beak length, tarsal circumference, drumstick length and circumference, comb length and height, barbel width and height, thoracic circumference, wing length and span.

\section{Carcass characteristics}

At the end of the trial, 3 hens and 3 roosters were randomly selected according to feathering type and sacrificed fasted to assess carcass characteristics. Data were collected on the weight of the following parts: carcass, thighs, wishbone, wings, head, legs, back, liver, heart, gizzard, gonads and abdominal fat. The data collected were used to calculate the following parameters:

- $\quad$ Carcass weight $=$ Live weight - weight (blood + feathers + entrails). 
- $\quad$ Carcass yield $(\%)=\frac{\text { Carcass weight }(g)}{\text { Live weight }(g)} \times 100$

- $\quad$ Relative weight of parts or organs (\%) $=\frac{\text { Weight of part or organ }(\mathrm{g})}{\text { Live weight }(\mathrm{g})} \times 100$

- Gonado-Somatic Index $=\frac{\text { Gonad weight }}{\text { Live weight }} \times 100$

- $\quad$ Shape index $=\frac{\text { Gonad diameter }}{\text { Gonad height }}$

\section{Statistical analyses}

Descriptive statistics were used to calculate frequencies and one-way analysis of variance (ANOVA) was used following the general linear model to compare the means of the growth parameters. When there were significant differences between the means, Duncan's test at the $5 \%$ threshold was used to separate means. Pearson's correlation test was used to determine the direction and degree of association between measurements. IBM SPSS Statistics 25.0 and Excel 2016 were used for the various analyses.

\section{Results and Discussion}

\section{Results}

\section{Morphological characteristics}

Feathering types

Three types of feathering were recorded: bare neck with feathered tarsi (CNTE), feathered tarsi (TE) and normal feathering (NF).

It can be seen from figure 1 that birds with feathered tarsi represent almost $80 \%$ of the overall size of the study population, while normal feathering represents only $5 \%$ of the chickens in this population.

\section{Eye and tarsal color}

Eye color (Figure 2) in the study population is brown, orange and yellow, with brown eyes representing $75.3 \%$ of the population and yellow eyes representing only $5.5 \%$.

Tarsal color distribution in the study population is shown in Figure 3.

Improved chickens have a variety of tarsi colors, with white being the most common (76.4\%) and grey the least common (4.1\%).

Beak coloration and shape

Figure 4 illustrates the distribution of beak coloration and shape in the improved chicken breeds. It can be seen that beak coloration is varied and the beaks observed were horn, brown horn, black horn, brown and black brown.

Black beaks were the most represented (47.9\%) followed by black horn (23.3\%) and the lowest percentage was noted with brown horn beaks $(2.7 \%)$. Despite the diversity of colors observed, all beaks (100\%) were curved.

Comb types

Combs observed were of three types: simple, triple and simple-curved (figure 5).

It appears that simple combs were the most represented with $75.3 \%$, while simple fallen combs were more absent (5.5\%).

Mumps shape

Mumps observed were round and oval in shape (Figure 6). The most frequent shapes were round $(71.2 \%)$ while oval shapes represented only $28.8 \%$ of the population studied.

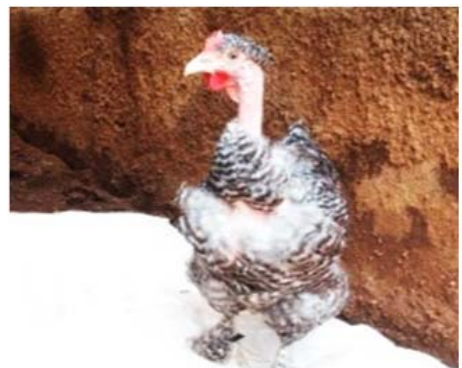

Bared neck and Feathered tarsus $16.4 \%$

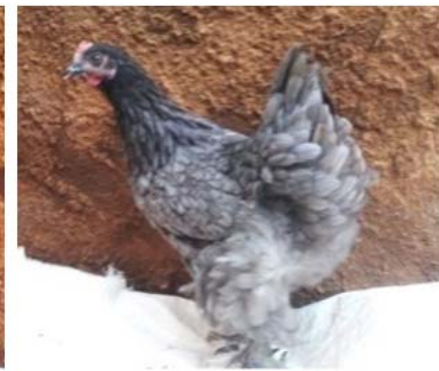

Feathered tarsus

$78.1 \%$

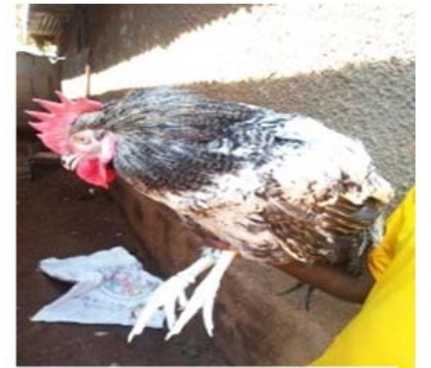

Normal feathering

$5.5 \%$

Figure 1. Feathering type and distribution 


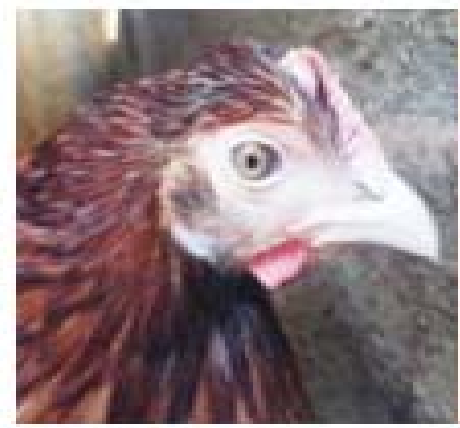

Brown $75.3 \%$

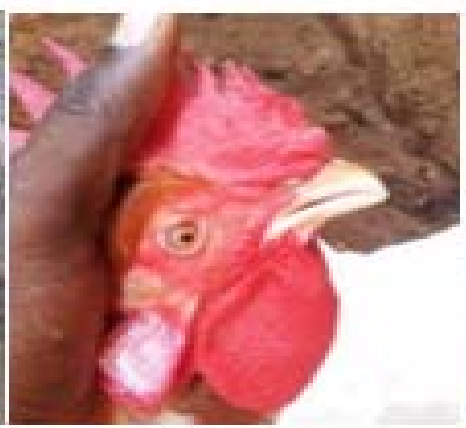

Orange

$19.2 \%$

Figure 2. Eye color and distribution

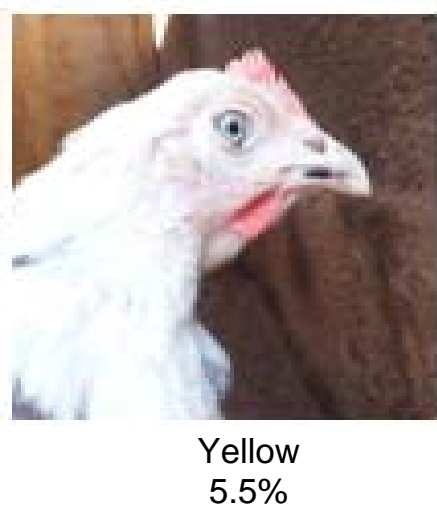

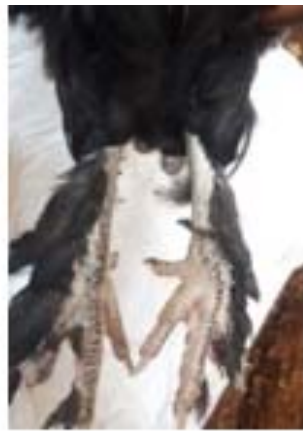

Black

$12.3 \%$

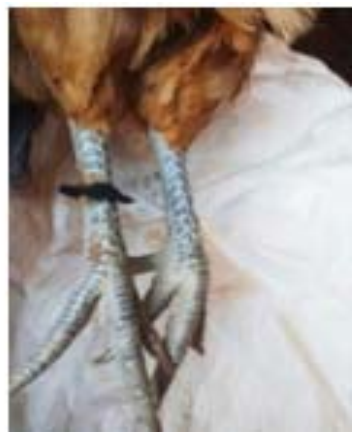

Green

$6.8 \%$

Figure 3. Tarsal color distribution

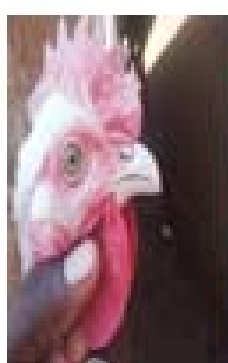

Horn $13.7 \%$

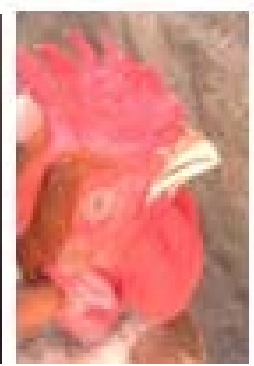

Brown horn $2.7 \%$

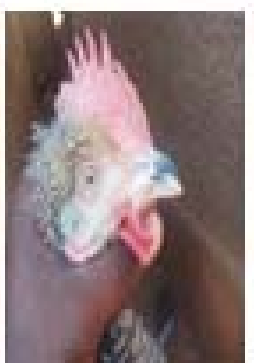

Black horn $23.3 \%$

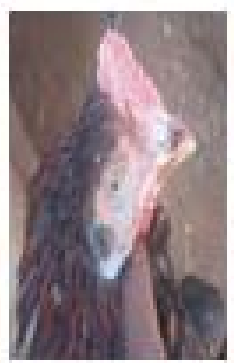

Brown

$6.8 \%$

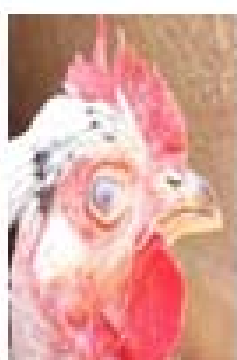

Brown black Horn black

$5.5 \%$

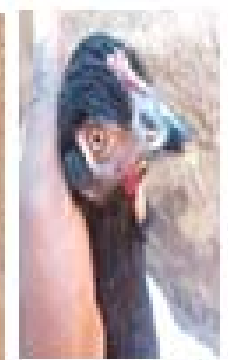

$47.9 \%$

Figure 4. Beak color distribution

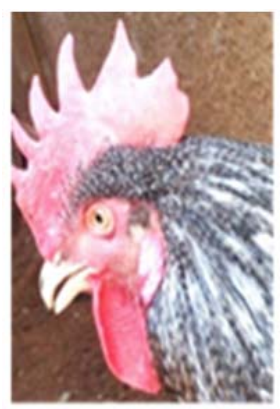

Single

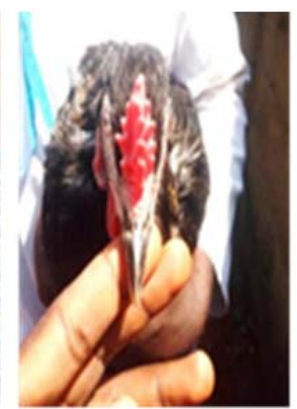

Triple

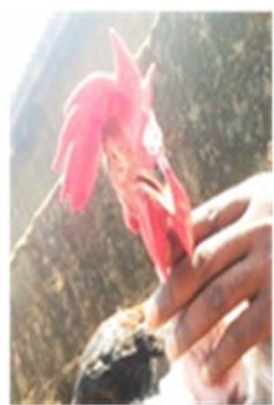

Single Fallen

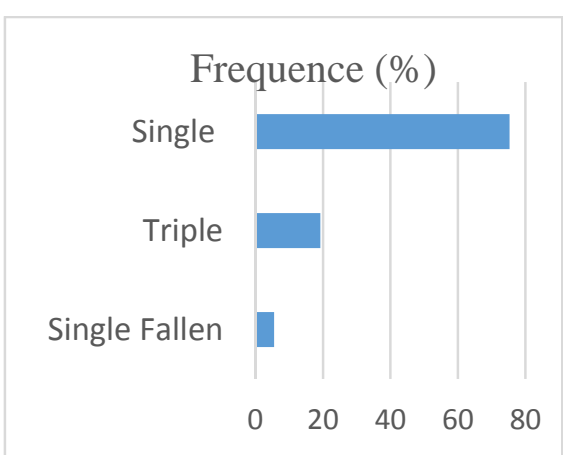

Figure 5. Comb type and distribution 

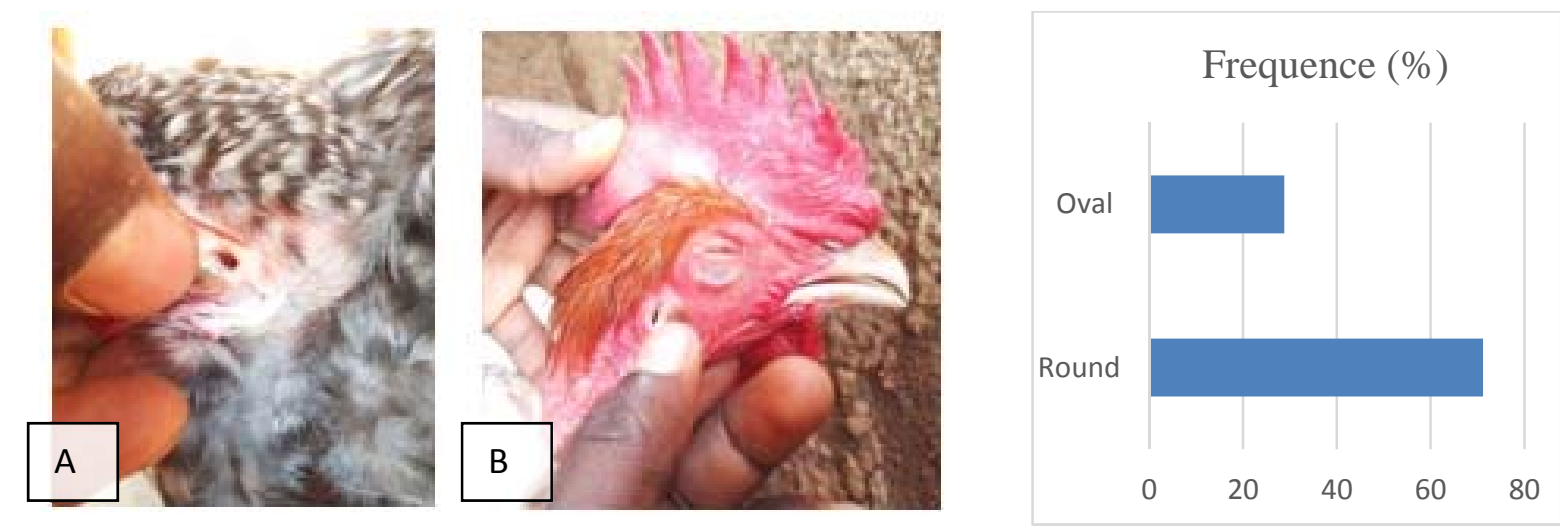

Figure 6: Mumps shape distribution

\section{Effect of phenotype on growth parameters Biometric characterization}

The evolution of body measurements in relation to morphological characteristics of 16-week-old exotic chickens is shown in Table 1. Body measurements varied and differed from one morphological characteristic to another, except for the color and circumference of the tarsi, which did not vary significantly $(P>0.05)$ regardless of the parameter considered.

Body length was significantly affected $(P<0.05)$ by feathering type and comb shape. The highest value was observed in hens expressing Dw+ (normal feathering) and Pti (feathered) tarsi. Similarly, this length was significantly higher in chickens with single fallen combs compared to those with single straight and threefold combs whose values were otherwise comparable.

Thorax circumference varied significantly $(P<0.05)$ with feathering type, comb shape and eye color. Hens with feathered tarsi had the lowest value, while brown and orange eyed birds had comparable but significantly lower thorax circumferences compared to yellow eyed birds. Chickens with a single fallen comb induced the highest value.

With the exception of tarsal length and thoracic circumference, which were similar regardless of comb shape, the single dropped comb chickens had significantly $(P<0.05)$ higher values than the other comb shapes. The length of the drumstick and tarsus in black-brown beaked hens was comparable to all other variables except that the brown color of the beak for drumstick length and the black color for tarsus length were significantly lower. For wing length, black-brown beaked chickens recorded the highest values, while single and threefold combed chickens induced significantly low but otherwise comparable values between them.

The drumstick circumference was significantly $(P<0.05)$ affected by feathering type, comb shape and eye color. It was observed that hens
A: Round shape B: Oval shape

expressing both bare neck and feathered tarsi traits induced the highest value as well as chickens with single dropped comb and those with yellowish eye.

Correlations between thorax and tarsal circumference and live weight at 16 weeks of age Correlations between live weight, thorax circumference and tarsus circumference at 16 weeks of age and according to the feathering type are shown in Table 2. Tarsus circumference was significantly and positively correlated with live weight and thorax circumference regardless of feathering type. The strongest correlations $(P<0.01)$ were found with normally feathered chickens, and there was also a positive correlation between tarsal and thoracic circumferences in birds with feathered tarsi.

Production performance in relation to morphological characteristics of exotic hens In Table 3, the growth performance of exotic chickens according to morphological characteristics at 16 weeks of age is presented. Except for tarsal color, growth performance was significantly affected by other morphological characteristics.

Feed intake was similar $(P>0.05)$ regardless of feathering type, comb shape, tarsal and eye color. The horn-billed and horn-black beaks had comparable and significantly higher values than the horn-brown beaks.

Live weight and average weekly weight gain of hens at 16 weeks of age showed the same trend and varied significantly $(P<0.05)$ with feathering type, comb shape and eye color. The values observed in bare neck hens with feathered tarsi and normal feathered hens were comparable and significantly higher than those obtained in hens with feathered tarsi. Live weights of single and threefold combed chickens were similar and significantly lower than those of single combed chickens. In terms of eye color, the significantly highest value was recorded for yellow-eyed chickens. However, live weight was not 


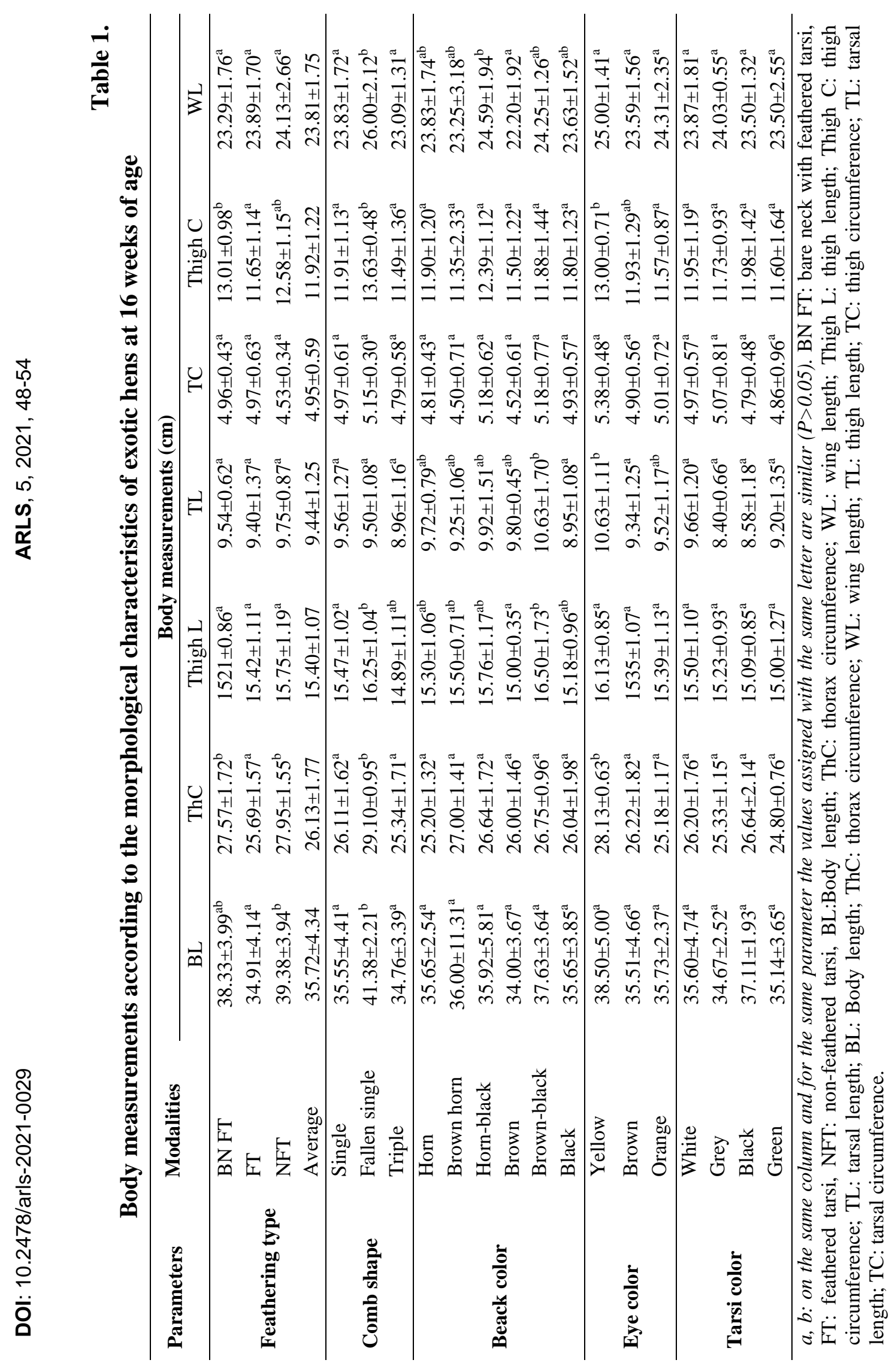


significantly affected $(P>0.05)$ by beak and tarsus color.

The feed conversion ratio (FCR) varied significantly $(P<0.05)$ with feathering type, comb shape and eye color. Feed conversion ratio values for bare-necked and tarsal feathered hens and normal feathered hens were comparable and significantly lower than those for tarsal feathered hens. Birds with single and triple combs induced comparable and significantly higher feed conversion ratios than those with a single fallen comb. Brown-eyed and orange-eyed hens had comparable and significantly higher feed conversion ratios than yellow-eyed hens. However, feed conversion was not significantly affected $(P>0.05)$ by beak and tarsal color.

Table 2.

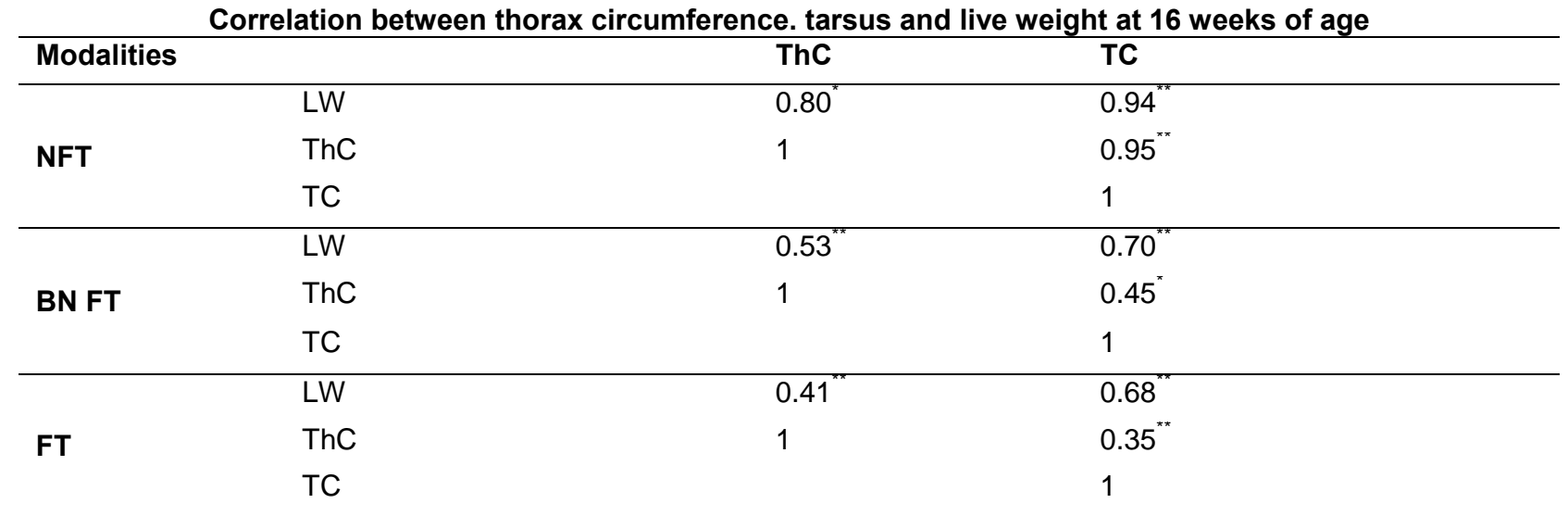

${ }^{* *}$ Correlation is significant at the 0.01 level and ${ }^{*}$ at the 0.05 level. BN FT: bare neck with feathered tarsi. FT: feathered tarsi. NFT: non-feathered tarsi. LW: Live weight; ThC: Thoracic Circumference. TC: Tarsal circumference

Table 3.

Growth performance of exotic hens as a function of morphological characteristics at 16 weeks of age

\begin{tabular}{|c|c|c|c|c|c|c|}
\hline & \multirow{2}{*}{ Modalities } & \multirow{2}{*}{$\mathbf{N}$} & \multicolumn{4}{|c|}{ Growth performance } \\
\hline & & & Feed Intake (g) & Live weight (g) & GMH (g) & IC Total \\
\hline \multirow{4}{*}{$\begin{array}{c}\text { Feathering } \\
\text { type }\end{array}$} & BN FT & 24 & $7133.64 \pm 890.19^{a}$ & $1758.00 \pm 322.20^{b}$ & $107.83 \pm 20.06^{b}$ & $4.28 \pm 0.97^{a}$ \\
\hline & FT & 114 & $7060.83 \pm 971.20^{\mathrm{a}}$ & $1373.25 \pm 261.73^{\mathrm{a}}$ & $83.62 \pm 16.26^{a}$ & $5.42 \pm 0.99^{b}$ \\
\hline & NFT & 8 & $6656.08 \pm 747.38^{a}$ & $1687.50 \pm 304.25^{b}$ & $103.27 \pm 18.93^{b}$ & $4.09 \pm 0.65^{a}$ \\
\hline & Average & 146 & $7050.62 \pm 942.26$ & $1453.71 \pm 310.79$ & $88.68 \pm 19.37$ & $5.15 \pm 1.08$ \\
\hline \multirow{3}{*}{$\begin{array}{l}\text { Comb } \\
\text { shape }\end{array}$} & Simple & 110 & $7030.96 \pm 1000.47^{a}$ & $1431.31 \pm 275.84^{a}$ & $87.24 \pm 17.23^{a}$ & $5.18 \pm 1.01^{b}$ \\
\hline & $\begin{array}{l}\text { Simple } \\
\text { fallen }\end{array}$ & 8 & $6902.19 \pm 803.92^{\mathrm{a}}$ & $1953.50 \pm 275.71^{b}$ & $119.87 \pm 16.96^{b}$ & $3.64 \pm 0.54^{\mathrm{a}}$ \\
\hline & Triple & 28 & $7170.25 \pm 765.86^{a}$ & $1398.93 \pm 345.18^{a}$ & $85.42 \pm 21.42^{a}$ & $5.48 \pm 1.17^{b}$ \\
\hline \multirow{6}{*}{ Beak color } & Horn & 20 & $7331.46 \pm 340.64^{b}$ & $1308.50 \pm 250.12^{a}$ & $79.70 \pm 15.62^{a}$ & $5.92 \pm 1.01^{\mathrm{a}}$ \\
\hline & Horn-brown & 4 & $5995.06 \pm 136.03^{a}$ & $1497.50 \pm 806.81^{a}$ & $91.46 \pm 50.58^{a}$ & $4.86 \pm 2.78^{\mathrm{a}}$ \\
\hline & Black horn & 34 & $7297.32 \pm 1091.81^{b}$ & $1628.76 \pm 318.40^{\mathrm{a}}$ & $99.48 \pm 19.91^{a}$ & $4.73 \pm 1.03^{\mathrm{a}}$ \\
\hline & Chestnut & 10 & $6451.11 \pm 803.80^{\mathrm{ab}}$ & $1388.40 \pm 208.83^{a}$ & $84.56 \pm 12.96^{a}$ & $4.84 \pm 0.75^{a}$ \\
\hline & $\begin{array}{l}\text { Brown- } \\
\text { black }\end{array}$ & 8 & $6844.15 \pm 1258.35^{\mathrm{ab}}$ & $1384.75 \pm 255.69^{a}$ & $84.34 \pm 16.08^{a}$ & $5.19 \pm 1.24^{\mathrm{a}}$ \\
\hline & Black & 70 & $7020.11 \pm 945.62^{\mathrm{ab}}$ & $1424.89 \pm 294.19^{a}$ & $86.92 \pm 18.30^{a}$ & $5.20 \pm 1.01^{\mathrm{a}}$ \\
\hline \multirow{3}{*}{ Eye color } & Yellow & 8 & $7073.11 \pm 986.53^{a}$ & $1828.00 \pm 268.01^{b}$ & $111.77 \pm 16.63^{b}$ & $4.02 \pm 0.72^{\mathrm{a}}$ \\
\hline & Chestnut & 110 & $7119.10 \pm 998.37^{\mathrm{a}}$ & $1444.35 \pm 308.61^{a}$ & $88.11 \pm 19.26^{a}$ & $5.24 \pm 1.10^{b}$ \\
\hline & Orange & 28 & $6775.17 \pm 671.30^{\mathrm{a}}$ & $1383.57 \pm 272.04^{a}$ & $84.31 \pm 16.95^{a}$ & $5.16 \pm 0.97^{b}$ \\
\hline \multirow{4}{*}{ Tarsal color } & White & 112 & $7127.89 \pm 899.97^{a}$ & $1468.46 \pm 307.41^{a}$ & $89.55 \pm 19.23^{a}$ & $5.17 \pm 1.11^{\mathrm{a}}$ \\
\hline & Grey & 6 & $6933.43 \pm 1541.40^{a}$ & $1286.00 \pm 160.41^{a}$ & $78.24 \pm 10.31^{a}$ & $5.52 \pm 0.73^{a}$ \\
\hline & Black & 18 & $6755.67 \pm 900.72^{\mathrm{a}}$ & $1432.67 \pm 316.73^{a}$ & $87.68 \pm 19.18^{a}$ & $5.01 \pm 1.19^{a}$ \\
\hline & Green & 10 & $6786.35 \pm 1287.23^{a}$ & $1427.00 \pm 446.83^{a}$ & $86.94 \pm 27.96^{a}$ & $5.09 \pm 0.97^{\mathrm{a}}$ \\
\hline
\end{tabular}

a. b: on the same column and for the same parameter the values assigned with the same letter do not vary significantly

$(P>0.05)$. BN FT: bare neck with feathered tarsi. FT: feathered tarsi. NFT: non-feathered tarsi. 
Carcass characteristics according to feathering type

Table 4 presents the carcass characteristics of chickens according to the feathering type. From this it can be seen that carcass yield, thigh, wing, leg and neck proportions were not significantly affected by feathering type. However, the relatively highest carcass yields were found with bare neck and feathered tarsi chickens. The relative weight of the breastbone did not vary significantly in males regardless of sex, whereas in females it was more developed in normally feathered chickens compared to feathered tarsi. The proportions of the breast bone in females and the back in males with bare necks and feathered tarsi were, however, similar to those of the other feathering types.

Table 4.

Carcass characteristics and proportion of various parts of improved hens according to feathering type

\begin{tabular}{|c|c|c|c|c|}
\hline Caracteristics & Modalities & Male & Female & Mixed \\
\hline \multirow{4}{*}{ Carcass yield } & BN FT & $69.94 \pm 0.89^{\mathrm{a}}$ & $69.99 \pm 2.14^{\mathrm{a}}$ & $6996 \pm 1.46^{\mathrm{a}}$ \\
\hline & $\mathrm{FT}$ & $68.32 \pm 2.02^{\mathrm{a}}$ & $67.87 \pm 5.01^{\mathrm{a}}$ & $68.09 \pm 3.42^{\mathrm{a}}$ \\
\hline & NFT & $69.48 \pm 1.12^{\mathrm{a}}$ & $69.88 \pm 2.05^{\mathrm{a}}$ & $69.68 \pm 1.49^{\mathrm{a}}$ \\
\hline & Average & $69,25 \pm 1.43$ & $69.25 \pm 3.08$ & $69.25 \pm 2.34$ \\
\hline \multirow{4}{*}{ Breast } & BN FT & $14.33 \pm 1.02^{\mathrm{a}}$ & $17.69 \pm 0.59^{\mathrm{ab}}$ & $16.01 \pm 1.98^{\mathrm{a}}$ \\
\hline & $\mathrm{FT}$ & $14.19 \pm 0.32^{\mathrm{a}}$ & $15.86 \pm 1.08^{\mathrm{a}}$ & $15.03 \pm 1.16^{\mathrm{a}}$ \\
\hline & NFT & $14.64 \pm 0.73^{\mathrm{a}}$ & $19.20 \pm 1.66^{\mathrm{b}}$ & $16.92 \pm 2.74^{\mathrm{a}}$ \\
\hline & Average & $14.38 \pm 0.68$ & $17.58 \pm 1.77$ & $15.98 \pm 2.10$ \\
\hline \multirow{4}{*}{ Thighs } & BN FT & $24.05 \pm 0.91^{\mathrm{a}}$ & $20.19 \pm 2.14^{\mathrm{a}}$ & $22.12 \pm 2.57^{\mathrm{a}}$ \\
\hline & FT & $17.29 \pm 9.31^{\mathrm{a}}$ & $19.46 \pm 0.55^{\mathrm{a}}$ & $18.38 \pm 6.02^{\mathrm{a}}$ \\
\hline & NFT & $23.45 \pm 0.19^{\mathrm{a}}$ & $21.38 \pm 0.09^{\mathrm{a}}$ & $22.42 \pm 1.14^{\mathrm{a}}$ \\
\hline & Average & $21.59 \pm 5.69$ & $20.35 \pm 1.38$ & $20.97 \pm 4.07$ \\
\hline \multirow{4}{*}{ Wings } & BN FT & $7.61 \pm 0.06^{\mathrm{a}}$ & $7.46 \pm 1.08^{\mathrm{a}}$ & $7.54 \pm 0.69^{\mathrm{a}}$ \\
\hline & $\mathrm{FT}$ & $7.86 \pm 0.28^{\mathrm{a}}$ & $7.44 \pm 0.80^{\mathrm{a}}$ & $7.65 \pm 0.58^{\mathrm{a}}$ \\
\hline & NFT & $7.86 \pm 0.26^{\mathrm{a}}$ & $8.11 \pm 1.04^{\mathrm{a}}$ & $7.98 \pm 0.69^{\mathrm{a}}$ \\
\hline & Average & $7.77 \pm 0.23$ & $7.67 \pm 0.91$ & $7.72 \pm 0.65$ \\
\hline \multirow{4}{*}{ Head } & BN FT & $3.76 \pm 0.10^{b}$ & $2.66 \pm 0.30^{\mathrm{a}}$ & $3.22 \pm 0.63^{\mathrm{a}}$ \\
\hline & FT & $3.17 \pm 0.04^{\mathrm{a}}$ & $2.46 \pm 0.13^{\mathrm{a}}$ & $2.82 \pm 0.39^{\mathrm{a}}$ \\
\hline & NFT & $3.56 \pm 0.21^{\mathrm{b}}$ & $2.39 \pm 0.01^{\mathrm{a}}$ & $2.98 \pm 0.65^{\mathrm{a}}$ \\
\hline & Average & $3.50 \pm 0.28$ & $2.51 \pm 0.20$ & $3.01 \pm 0.56$ \\
\hline \multirow{4}{*}{ Legs } & BN FT & $467 \pm 0.67^{\mathrm{a}}$ & $3.38 \pm 0.41^{\mathrm{a}}$ & $4.03 \pm 0.86^{\mathrm{a}}$ \\
\hline & FT & $4.03 \pm 0.86^{\mathrm{a}}$ & $3.26 \pm 0.08^{\mathrm{a}}$ & $3.65 \pm 0.69^{\mathrm{a}}$ \\
\hline & NFT & $4.48 \pm 0.02^{\mathrm{a}}$ & $3.67 \pm 0.23^{\mathrm{a}}$ & $4.07 \pm 0.47^{\mathrm{a}}$ \\
\hline & Average & $4.39 \pm 0.62$ & $3.44 \pm 0.29$ & $3.92 \pm 0.68$ \\
\hline \multirow{4}{*}{ Back } & BN FT & $16.49 \pm 0.45^{\mathrm{ab}}$ & $17.35 \pm 2.02^{\mathrm{a}}$ & $16.92 \pm 1.39^{\mathrm{a}}$ \\
\hline & $\mathrm{FT}$ & $15.86 \pm 0.54^{\mathrm{a}}$ & $15.84 \pm 0.75^{\mathrm{a}}$ & $15.85 \pm 0.58^{\mathrm{a}}$ \\
\hline & NFT & $16.87 \pm 0.25^{b}$ & $15.26 \pm 0.66^{\mathrm{a}}$ & $16.06 \pm 0.98^{\mathrm{a}}$ \\
\hline & Average & $16.41 \pm 0.57$ & $16.15 \pm 1.46$ & $16.28 \pm 1.08$ \\
\hline \multirow{4}{*}{ Neck } & BN FT & $6.27 \pm 0.13^{\mathrm{a}}$ & $5.58 \pm 0.62^{\mathrm{a}}$ & $5.93 \pm 0.55^{\mathrm{a}}$ \\
\hline & $\mathrm{FT}$ & $6.30 \pm 0.61^{\mathrm{a}}$ & $5.29 \pm 0.44^{\mathrm{a}}$ & $5.79 \pm 0.73^{\mathrm{a}}$ \\
\hline & NFT & $6.25 \pm 0.27^{\mathrm{a}}$ & $5.75 \pm 0.36^{\mathrm{a}}$ & $5.99 \pm 0.39^{\mathrm{a}}$ \\
\hline & Average & $6.27 \pm 0.34$ & $5.54 \pm 0.46$ & $5.91 \pm 0.55$ \\
\hline
\end{tabular}

$a, b$ : on the same column and for the same parameter the values assigned with the same letter do not vary significantly $(P>0.05)$. BN FT: bare neck with feathered tarsi, FT: feathered tarsi, NFT: non-feathered tarsi.

Proportions of organs and abdominal fat according to feathering type.

The changes in organ proportions as a function of feathering type are summarized in Table 5. It reveals that most organs and abdominal fat were not significantly $(P>0.05)$ affected by feathering type. However, it was observed that regardless of sex, viscera were more developed in birds with feathered tarsi but were similar to those with bare necks and feathered tarsi, which in turn were 
similar to normal feathering, while there was significant variation $(\mathrm{P}<0.05)$ in gizzard and proventricular values in males. These values were highest in feathered tarsus and bare neck feathered tarsus males respectively compared to normal feathered chickens.
Regardless of sex, the relative gizzard weight was highest with feathered tarsi compared to the other feathering types, which otherwise had comparable values.

Proportions of some organs and abdominal fat according to the feathering type

\begin{tabular}{|c|c|c|c|c|}
\hline Characteristics & Modalities & Male & Female & Mixed \\
\hline \multirow{4}{*}{ Viscera } & BN FT & $11.54 \pm 0.66^{\mathrm{a}}$ & $11.95 \pm 0.85^{\mathrm{a}}$ & $11.75 \pm 0.72^{a b}$ \\
\hline & TE & $11.74 \pm 2.46^{a}$ & $15.27 \pm 3.88^{a}$ & $13.51 \pm 3.50^{b}$ \\
\hline & NFT & $9.47 \pm 0.34^{\mathrm{a}}$ & $10.66 \pm 0.97^{\mathrm{a}}$ & $10.07 \pm 0.93^{\mathrm{a}}$ \\
\hline & Average & $10.92 \pm 1.68$ & $12.63 \pm 2.91$ & $11.77 \pm 2.47$ \\
\hline \multirow{4}{*}{ Liver } & $\mathrm{BN} F \mathrm{~F}$ & $1.42 \pm 0.06^{\mathrm{a}}$ & $1.92 \pm 0.38^{\mathrm{a}}$ & $1.67 \pm 0.37^{\mathrm{a}}$ \\
\hline & $\mathrm{TE}$ & $1.45 \pm 0.36^{\mathrm{a}}$ & $1.50 \pm 0.13^{\mathrm{a}}$ & $1.47 \pm 0.25^{\mathrm{a}}$ \\
\hline & NFT & $1.27 \pm 0.14^{\mathrm{a}}$ & $1.75 \pm 0.28^{\mathrm{a}}$ & $1.51 \pm 0.33^{\mathrm{a}}$ \\
\hline & Average & $1.38 \pm 0.21$ & $1.72 \pm 0.31$ & $1.55 \pm 0.31$ \\
\hline \multirow{4}{*}{ Heart } & $\mathrm{BN} F \mathrm{~T}$ & $0.59 \pm 0.12^{a}$ & $0.61 \pm 0.15^{a}$ & $0.60 \pm 0.12^{\mathrm{a}}$ \\
\hline & TE & $0.58 \pm 0.06^{a}$ & $0.42 \pm 0.05^{\mathrm{a}}$ & $0.51 \pm 0.10^{\mathrm{a}}$ \\
\hline & NFT & $0.66 \pm 0.03^{a}$ & $0.46 \pm 0.07^{\mathrm{a}}$ & $0.56 \pm 0.12^{\mathrm{a}}$ \\
\hline & Average & $0.61 \pm 0.07$ & $0.49 \pm 0.12$ & $0.56 \pm 0.12$ \\
\hline \multirow{4}{*}{ Gizzard } & BN FT & $2.43 \pm 0.63^{\text {ab }}$ & $2.38 \pm 0.43^{a}$ & $2.40 \pm 0.48^{\mathrm{a}}$ \\
\hline & TE & $2.91 \pm 0.22^{b}$ & $3.02 \pm 0.26^{\mathrm{a}}$ & $2.96 \pm 0.23^{b}$ \\
\hline & NFT & $1.95 \pm 0.25^{\mathrm{a}}$ & $2.66 \pm 0.22^{\mathrm{a}}$ & $2.31 \pm 0.45^{a}$ \\
\hline & Average & $2.43 \pm 0.55$ & $2.69 \pm 0.39$ & $2.56 \pm 0.48$ \\
\hline \multirow{4}{*}{ Proventricle } & $\mathrm{BN} \mathrm{FT}$ & $0.45 \pm 0.08^{b}$ & $0.48 \pm 0.15^{a}$ & $0.46 \pm 0.11^{\mathrm{a}}$ \\
\hline & TE & $0.39 \pm 0.06^{a b}$ & $0.56 \pm 0.05^{\mathrm{a}}$ & $0.47 \pm 0.10^{\mathrm{a}}$ \\
\hline & NFT & $0.29 \pm 0.002^{a}$ & $0.45 \pm 0.04^{\mathrm{a}}$ & $0.37 \pm 0.09^{\mathrm{a}}$ \\
\hline & Average & $0.38 \pm 0.08$ & $0.49 \pm 0.09$ & $0.44 \pm 0.11$ \\
\hline \multirow{4}{*}{ Abdominal fat } & BN FT & $1.75 \pm 1.15^{\mathrm{a}}$ & $3.60 \pm 2.96^{\mathrm{a}}$ & $2.67 \pm 2.25^{\mathrm{a}}$ \\
\hline & TE & $2.02 \pm 0.14^{\mathrm{a}}$ & $3.02 \pm 1.94^{\mathrm{a}}$ & $2.52 \pm 1.35^{\mathrm{a}}$ \\
\hline & NFT & $0.93 \pm 0.09^{\mathrm{a}}$ & $5.01 \pm 0.12^{\mathrm{a}}$ & $2.97 \pm 2.24^{\mathrm{a}}$ \\
\hline & Average & $1.56 \pm 0.76$ & $3.88 \pm 1.97$ & $2.72 \pm 1.87$ \\
\hline
\end{tabular}

$a, b:$ on the same column and for the same parameter the values assigned with the same letter do not vary significantly $(P>0.05)$. BN FT: bare neck with feathered tarsi, TE: feathered tarsi, NFT: non-feathered tarsi.

\section{Testicular characteristics according to feathering type.}

Characteristics of the testes according to the type of feather are shown in Table 6 . It can be seen that testicular weight, height and diameter were not significantly affected $(P>0.05)$. However, the highest values of average testes weight and height $(15.04 \pm 6.96 \mathrm{~mm} ; 46.02 \pm 5.49 \mathrm{~mm})$ were recorded in males with naked neck traits with feathered tarsi and the lowest $(11.56 \pm 3.46 \mathrm{~mm}$; $40.03 \pm 4.41 \mathrm{~mm}$ ) in males expressing the Pti gene. For testis diameter the highest value (26.79 \pm 1.75$)$ was recorded in males expressing the Dw+ gene and the lowest $(24.46 \pm 5.38 \mathrm{~mm})$ in males expressing the $\mathrm{Na}$ and Pti genes. However, the shape index varied significantly $(P<0.05)$ according to the type of root. The shape index of the testes in Pti expressing males $(0.63 \pm 0.02 \%)$ was significantly higher than that of $\mathrm{Na}$ - and Pti expressing males $(0.53 \pm 0.06 \%)$, both comparable to that of Dw+ expressing hens (0.59 $\pm 0.01 \%)$.

\section{Discussion}

This study presents the morpho-biometric characteristics and growth performance of exotic hens reared in the city of Ngaoundéré.

The distribution of plumage in the populations studied could be explained by the interaction between the genotype and the selection and rearing environments of the improved chickens $[3,10]$. The high representation of hens with feathered tarsi and bare necks is a consequence of the relative homogeneity of the geoclimatic conditions in the areas of origin of the majority of the local improved chickens, which are said to be of Asian origin. It is also known that phenotypes such as the naked neck are the result of anatomical and physiological modifications, linked to genes, allowing better heat dissipation [11] or resistance to cold for breeds with feathered tarsi such as the French Orpington.

Regarding morphological characteristics, in the studied chicken population, three types of combs were observed: single, single dropped and 
threefold with a dominance of the single comb. These observations are similar to those made by Keambou et al, [5], Fotsa et al, [6], Bembide et al,
[12] and opposite to those of Getu et al, [13] who had rather observed a dominance of double combs.

Table 6.

Testicular characteristics according to the feathering type

\begin{tabular}{|c|c|c|c|c|}
\hline Characteristics & Modalities & BN FT & $\mathbf{F T}$ & NFT \\
\hline \multirow{3}{*}{ Testicular weight (g) } & Left & $16.18 \pm 7.94^{\mathrm{a}}$ & $11.92 \pm 3.35^{\mathrm{a}}$ & $14.83 \pm 2.08^{\mathrm{a}}$ \\
\hline & Right & $13.89 \pm 5.99^{\mathrm{a}}$ & $11.22 \pm 4.18^{\mathrm{a}}$ & $1501 \pm 1.89^{\mathrm{a}}$ \\
\hline & Average & $30.07 \pm 6.96^{\mathrm{a}}$ & $23.14 \pm 3.46^{\mathrm{a}}$ & $29.84 \pm 1.98^{\mathrm{a}}$ \\
\hline \multirow{3}{*}{ Testicular height (mm) } & Left & $45.87 \pm 5.78^{\mathrm{a}}$ & $40.90 \pm 4.83^{\mathrm{a}}$ & $45.85 \pm 4.35^{\mathrm{a}}$ \\
\hline & Right & $46.16 \pm 6.24^{\mathrm{a}}$ & $39.16 \pm 4.04^{\mathrm{a}}$ & $44.85 \pm 2.95^{\mathrm{a}}$ \\
\hline & Average & $46.02 \pm 5.49^{a}$ & $40.03 \pm 4.41^{\mathrm{a}}$ & $45.35 \pm 3.65^{\mathrm{a}}$ \\
\hline \multirow{3}{*}{ Testicular diameter (mm) } & Left & $25.16 \pm 5.91^{\mathrm{a}}$ & $26.66 \pm 1.07^{\mathrm{a}}$ & $26.00 \pm 2.60^{\mathrm{a}}$ \\
\hline & Right & $23.76 \pm 4.89^{\mathrm{a}}$ & $24.16 \pm 3.54^{\mathrm{a}}$ & $27.60 \pm 0.90^{\mathrm{a}}$ \\
\hline & Average & $24.46 \pm 5.38^{a}$ & $25.42 \pm 2.24^{\mathrm{a}}$ & $26.79 \pm 1.75^{\mathrm{a}}$ \\
\hline \multirow{3}{*}{ Testis shape index (\%) } & Left & $0.54 \pm 0.06^{\mathrm{a}}$ & $0.66 \pm 0.06^{b}$ & $0.56 \pm 0.003^{\mathrm{ab}}$ \\
\hline & Right & $0.51 \pm 0.05^{\mathrm{a}}$ & $0.61 \pm 0.03^{b}$ & $0.62 \pm 0.02^{\mathrm{b}}$ \\
\hline & Average & $0.53 \pm 0.06^{\mathrm{a}}$ & $0.63 \pm 0.02^{b}$ & $0.59 \pm 0.01^{\mathrm{ab}}$ \\
\hline Gonado-somatic index (\%) & & $1.13 \pm 0.45^{\mathrm{a}}$ & $1.02 \pm 0.30^{\mathrm{a}}$ & $1.28 \pm 0.06^{\mathrm{a}}$ \\
\hline
\end{tabular}

$a, b$ : on the same line and for the same parameter the values assigned with the same letter do not vary significantly $(P>0.05)$. BN FT: bare neck with feathered tarsi, FT: feathered tarsi, NFT: non-feathered tarsi.

Six beak colors were observed: horn, horn-brown, horn-black, brown, brown-black and black. The black color was in the majority. This result is contrary to those of Keambou et al, [5], Mahammi et al, [14] and Messabhia, [15] who had observed a dominance of horn colored beaks. However, only curved beaks were observed. This shape was also observed by Messabhia, [15] contrasting to Keambou et al, [5], Bembide et al, [12] who had noted two beak shapes (curved and straight) with the curved shape dominating.

Three eye colors were identified in different proportions: brown (75.3\%), orange (19.2\%) and yellow (5.5\%). These results are different from those of Keambou et al, [5]; Yapi-Gnaore et al, [16] and Messabhia [15], who observed a dominance of orange-eyed hens.

Both mumps shapes were observed with a dominance of the round shape. This result is identical to that of Messabhia, [15] and contrary to those of Keambou et al, [5], Bembide et al, [12] and Mahammi et al, [14] who noted a predominance of oval shape.

The white color of the tarsi dominates over the black, green and grey colors. These results corroborate those of Keambou et al, [5] but are contrary to those of Fotsa et al, [6], Bembide et al, [12]; Moreda et al, [17] and Sarker et al, [18] who found a dominance of yellow tarsi. These variations would be linked not only to genetic variability, but also to physiological phenomena that would occur during reproduction or following a pathology such as cholera, the effect which could lead to a change in tarsal color [19].
The high variability of the different morphological characteristics could reflect the richness of the improved poultry genetic resources in the studied population $[20,21]$, but also the generally anarchic crossbreeding observed in the breeding farms [22, 23, 24].

The highest tarsal circumference was recorded in chickens with feathered tarsi in contrast to Messabhia [15] who reported a higher tarsal circumference in chickens with bare necks in Algeria. However, the average tarsal circumference values recorded were higher than those reported by Loukou, [25] in Côte d'Ivoire which could be explained by the feathers present on the tarsus in this genetic type.

The highest value of drumstick circumference in relation to feathering type was recorded in barenecked and feathered tarsal chickens; this is in agreement with the observations noted by Bembide et al, [12] in the Central African Republic but contrary to that recorded by Messabhia, [15] in Algeria who rather observed a higher development in combed head chickens.

In our study, bare-necked chickens with feathered tarsi had the highest live weight. This is contrary to those recorded by Bembide et al. [12] in the Central African Republic and Razakavololona [26] in Madagascar who reported that chickens with feathered tarsi were heavier. This may be explained by the early age of the naked and normal neck genetic type [7].

Depending on the shape of the comb, the lowest live weight recorded in triple-combed chickens could be explained by the fact that the P-gene 
responsible for this type of comb reduces the frequency of feathering of the breast and improves late growth in the young [27]. Chickens with feathered tarsi were the most represented in our study, but their average weight was lower than that of normally feathered chickens as well as in bare-necked and feathered tarsi hens. This suggests that the feathered tarsal trait is not necessarily linked to high live weight, although breeders consider it to be a selection criterion for hens with high meat production potential. The highest feed conversion ratio was recorded in chickens with feathered tarsi and could be explained by the growth delay also described by Hako et al. [7]. This feed conversion ratio was lower than the one recorded by Bello et al, [28] in Senegal on native hens.

Our chickens' carcass yield was higher than the one found by Fotsa et al, [29] in local chickens in Central, Southern, North-Western and Western Cameroon. On the other hand, Messabhia, [15] in Algeria obtained a higher carcass yield than that of ours in laying hens. The proportions of breast and wings recorded were lower than those observed by Kouadio et al, [30] in Côte d'Ivoire on 183-day old local hens. However, the thigh proportions of hens with feathered tarsi were higher than those observed by Kouadio et al. [30]. Neck proportions were higher than those obtained by Fotsa et al. [29] in males of local hens in Cameroon. The same applied to leg proportions in males, which were higher than those recorded by Fotsa et al, [29] in males of local hens. However, they were lower than those observed by Kouadio et al, [30] in Côte d'Ivoire on 183-day old local hens.

Liver proportions in males were lower than those recorded by Fotsa et al, [29] in native roosters but regardless of sex, liver and gizzard proportions were lower than those observed by Kouadio et al, [30] in Côte d'Ivoire in free-ranging local hens. This could be explained by genetic type, diet and rearing system [30]. Heart proportions in males were greater than those observed by Fotsa et al, [29]. However, irrespective of sex, heart proportions were greater than those of chickens reared in a semi-intensive system and lower than those reared in a free-range system reported by Kouadio et al. [30] in Côte d'Ivoire.

\section{Conclusions}

The aim of this study was to describe the phenotypic and zootechnical characteristics of the improved exotic chicken strains in the city of Ngaoundéré in Cameroon. It was found that there is morphological and biometric diversity within the exotic hen population studied. Weekly weight gain varied throughout the rearing period and was significantly affected by phenotype except for eye and tarsal color. Standard carcass yield did not vary significantly with sex. Similarly, testicular weight did not vary significantly with feathering type but was highest in chickens expressing the $\mathrm{Na}$ and Pti genes.

The observed phenotypical diversity and zootechnical characteristics suggest that exotic hens constitute an interesting poultry genetic resource but a better management strategy needs to be considered in order to preserve the local poultry resources.

\section{References}

1. Zaman, M.A., Sorensen, P., and Howlider, M.R. (2006). Egg production performances of a breed and three crossbreeds under semi scavenging system of management. Livestock Research for Rural Development, 2004, Volume 16, Article 60. http://www.Irrd.org//rrd16/8/zama16060.htm

2. MINEPIA. (2009). Master plan for the development of livestock sectors in Cameroon. Vol. II: Mapping of the sectors. Yaoundé, Cameroon, $82 \mathrm{p}$.

3. Fotsa, J.C., Poné, D.K., Manjeli, Y., et Mafeni, Mase, J. (2007). Study of breeding systems and phenotypic description of local hens (Gallus gallus in the rural forest zone of Cameroon). Journal of Agricultural Science Vol.3 No.1.

4. Bordas, A., Tixier-Boichard, M., Rognon, X., and Ben, abdel, jelil, K. (2004). Characterization and use of local poultry genetic resources in hot climates. Book of abstracts of the XXII World's Poultry Congress. Istanbul, Turkey, June, 8-13, 2004.

$5 . \quad K e a m b o u$, T.C., Manjeli, Y., Tchoumboue, J., Teguia, A., et Iroume, R.N. (2007). Morphobiometric characterisation of the genetic resources of local chickens in the highlands of western Cameroon. Livestock Research for Rural Development. Volume 19, Article \#107. http://www.Irrd.org//rrd19/8/keam19107.htm

$6 . \quad$ Fotsa J.C., Rognon X., TixierBoichard, M., Coquerelle G., Poné-Kamdem D., Ngou-Ngoupayou J.D., Manjeli Y., et Bordas A. (2010). Phenotypic characterisation of local chicken (Gallus gallus) populations in the dense humid forest zone with bimodal rainfall in Cameroon. Animal Genetic Resources46: 46-59. DOI: https://doi.org/10.1017/S207863361000069X

$7 . \quad$ Hako,Touko, B.A., Y. Manjeli, A. Téguia, et J. Tchoumboué. (2009). Evaluation and prediction of the effect of genetic type of local fowl (Gallus domesticus) on live body weight in Cameroon (Gallus domesticus). Livestock Research for Rural Development. 21: Article \#31., from http:// www.Irrd.org/lrrd21/3/hako21031.htm.

8. Djitie, F.K., Megueni, C., Teguia, A., \& Bitom, D.L. (2015). Socio-economic and technical survey on family poultry farming in the Adamaoua region, Cameroon, Livestock Research for Rural Development, 27 (2) : 1-14. http://www.Irrd.org//rrd27/2/djit27020.htm 
9. FAO. (2013). Phenotypic characterisation of animal genetic resources. FAO Directive on Animal Production and Health. $\mathrm{N}^{\circ}$ 11. Rome: 152p.

10. Bahy, A.A., Mohammed, M.M.A., and Osama, M.A. (2003). Relationship between genetic similarity and some productive traits in local chicken strains. African Journal of Biotechnology Volume 2 (2) pp 46-47.

11. Al-Rawi, A.A., and Al-Athari, A.K. (2002). Characteristics of indigenous chickens in Iraq. AGRI, 32: 87-93

12. Bembide C., B.A. Hako, Touko, Y., Manjeli, et Keambou, Tiambo, C. (2013). Morphobiometric characterisation of the local hen in the Central African Republic. Animal Genetic Resources, 2013, 53, 33-44. Food and Agriculture Organization of the United Nations, 2013

DOI: https://doi.org/10.1017/S2078633612000525

13. Getu, A., Alemayehu, K., et Wuletaw, Z. (2014). Phenotypic characterization of Indigenous Chicken Ecotypes in North Gondar Zone, Ethiopia. Global Veterinaria12 (3) : 361-368

14. Mahammi, F.Z., Gaouar, S.B.S., Tabet-Aoul, N., Tixier-Boichard, M., Saïdi-Mehtar, N. (2014). Morpho-biometric characteristics and breeding systems of local hens in western Algeria (Oranie). CahAgric 23 : 1-11. https://doi.org/10.1684/agr.2014.0722

15. Messabhia, Manel. (2016). Phenotypic characterisation and biochemical profile of some local chicken strains. Veterinary medicine thesis. Université des Frères Mentouri Constantine.

16. Yapi-Gnaore, C.V., Loukou, N.E., Kayang, B., Rognon, X., Tixier-boichar, M., Touré, G., Coulibaly, Y., N'Guetta, A.S.P., Youssao, Y. (2010). Phenotypic and morphometric diversity of local chickens (Gallus gallus) in two agro-ecological zones of Côte d'Ivoire. CahAgric 2010; 19 : 439-45 https://doi.org/10.1684/agr.2010.0436.

17. Moreda, E., Singh, H., Sisaye, T., \& Johansson, A.M. (2014). Phenotypic characterization of Indigenous Chicken population in South West and South Part of Ethiopia. British Journal of Poultry Sciences, 3 (1): 15-19.

18. Sarker, N.R., Hoque, A., Faruque, S., Islam, N., \& Bhuiyan, F.H. (2014). An ex situ study on body characteristics and effect of plumage color on body weight of indigenous chicken (Gallus domesticus) in Bangladesh. Maringá, 36 (1): 79-84. 3.

19. Ensminger, M.E. (1980). Poultry science

(Animal Agriculture series), 2nde edition. The Interstate Printers and Publisher, INC. 502p

$20 . \quad$ Fayeye, T.R., Ayorinde K.L., Ojo, V., and Adesina, O.M. (2006). Frequency and influence of some major genes on body weight and body size parameters of Nigerian local chickens. LivestResRur Dev, 18: 37-41.
http://www.Irrd.org//rrd18/3/faye18037.htm

21. Aklilu, H.M. (2007). Village poultry in Ethiopia; socio-technical analysis and learning with farmers. Ph.D. Thesis Wageningen University, Wageningen, Netherlands.

22. Cabarles, J.C. Jr., Lambio, A.L., Vega, S.A., Capitan, S.S., and Mendioro, M.S. (2012). Distinct morphological features of traditional chickens (Gallus gallus domesticus L.) in Western Visayas, Philippines. Animal Genetic Resources, 2012, 51, 73-87. Food and Agriculture Organization of the United Nations, 2012 DOI: https://doi.org/10.1017/S2078633612000410

23. Aberra, M. et Tegene, N. (2011). Phenotypic and morphological characterization of indigenous chicken populations in southern region of Ethiopia. Animal Genetic Resources, 2011, 49, 19-31. Food and Agriculture Organization of the United Nations, 2011 DOI: https://doi.org/10.1017/S2078633611000099

24. Monnet., L.B., Bordas, A., et Mérat, P. (1979). Monnet, L. E., Bordas, A., \& Merat, P. (1979). Naked neck gene and growth performance of chicks according to ambient temperature. Annals of Animal Genetics and Breeding 12 (3): 241-254.

25. Loukou, N.E. (2013). Phenotypic and molecular characterisation of local hens (Gallus gallus domesticus Linnaeus, 1758) from two agro-ecological zones in Côte d'Ivoire. Thèse Doctorat Phd. Université Félix Houphouët-Boigny. 206P.

26. Razakavololona, A.N.C. (2017). Morphobiometric characteristics and performance of local Kianjasoa chickens. Doctor in Veterinary Medicine. University of Antananarivo.

27. Horst, P. (1989). Native fowl as reservoir for genomes and major genes with direct and indirect effects on the adaptability and their potential for tropically orientated breeding plans. Archiv fuer Gefluegelkunde (Germany, FR).

28. Bello, H. (2010). Essay on the incorporation of Moringa oleifera leaf meal in the feed of indigenous chickens in Senegal: Effects on growth performance, carcass characteristics and economic results. Thesis: Méd. Vèt. Dakar.

29. Fotsa J.C., Bordas André, Rognon X., Tixier-Boichard Michèle, Poné Kamdem Dieudonné, Manjeli Y. (2007). Characterisation of local flocks and hens and on-station comparison of their performance with that of a commercial label strain in Cameroon. Seventh Aviculture Research Days, Tours, 28 and 29 March 2007 414-417.

30. Kouadio, K.E., Kouao, B.J., Kouadja, G.S., Fantodji, A., et Yapi, A.Y.L. (2010). Influence of the rearing system on the physical characteristics of carcasses of local chickens (Gallus gallus domesticus) in the humid forest region of Côte d'Ivoire. Int. J. Biol. Chem. Sci. 4(6): 2294-2302. 